\title{
Rancang Bangun Sistem Manajemen Budidaya Ayam Broiler Berbasis Web Menggunakan Metode Prototyping
}

\author{
Ridho Hawali Fani ${ }^{\# 1}$, Ibnu Surya ${ }^{* 2}$, Maksum Ro’'is Adin Saf ${ }^{\# 3}$

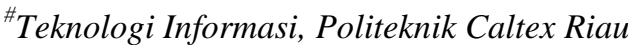 \\ Jl. Umban Sari ( Patin ) No. 1, Rumbai, Umban Sari, Rumbai, Kota Pekanbaru, Riau 28265 \\ ${ }^{1}$ ridhohawali.rhegmail.com \\ ${ }^{3}$ maksumepcr.ac.id \\ *Politeknik Caltex Riau \\ Jl. Umban Sari ( Patin ) No. 1, Rumbai, Umban Sari, Rumbai, Kota Pekanbaru, Riau 28265 \\ ibnuepcr.ac.id
}

\begin{abstract}
Abstrak -- Beternak dengan sistem kemitraan merupakan suatu bentuk usaha yang sedang marak saat ini, beternak secara kemitraan merupakan bentuk kerja sama antara peternak dengan perusahaan. Hasil panen akan dibagi sesuai persenan yang telah disepakati pada Memorandum of Understanding (MoU). Dibutuhkan waktu lebih kurang 4-6 minggu bagi peternak untuk memelihara ayam hingga panen. Selama periode tersebut, peternak harus merawat ayam dengan maksimal sehingga diharapkan hasil panen menguntungkan bagi peternak dan perusahaan tersebut. Maka dari itu, sistem ini dibangun agar dapat mengatasi permasalahan seperti pemberian pakan atau vaksin yang tidak teratur, pencatatan perkembangan ayam tiap hari yang masih dilakukan secara manual, penanganan penyakit dan kurangnya wawasan terhadap penyakit yang sering didapatkan oleh ayam, serta penghitungan timbangan yang masih dilakukan secara manual. Sehingga dengan mengatasi permasalahan tersebut hasil panen menjadi meningkat dan tingkat produktifitas ayam menjadi terkendali. Tools yang digunakan dalam pembuatan sistem ini adalah Visual Studio 2017. Setelah dilakukan pengujian selama tiga periode ternak, sebanyak $82.6 \%$ responden dari sepuluh orang yang merupakan peternak ayam broiler menyatakan sistem tersebut dapat meningkatkan efisiensi dalam beternak ayam broiler.
\end{abstract}

Kata kunci - Sistem Manajemen, Ayam Broiler, ASP.NET, Metode Prototyping, Kesejahteraan Pangan

\section{PENDAhUluan}

\section{Latar Belakang}

Kebutuhan protein hewani sangat penting dalam kehidupan manusia, oleh karena itu saat ini banyak wirausahawan yang melakukan usaha produksi pada hewan ternak, salah satunya beternak ayam broiler. Ayam broiler atau lebih dikenal dengan ayam potong atau pedaging merupakan ayam yang dapat dipanen pada waktu yang relatif singkat (Fatoni, 2011).
Konsep kemitraan dengan sistem kontrak atau yang lebih dikenal masyarakat dengan sistem kemitraan adalah perusahaan inti berkewajiban menyediakan sapronak (pakan, DOC, dan OVK) dan tenaga pembimbing teknis, sedangkan peternak yang bertindak sebagai mitra berkewajiban menyediakan kandang, peralatan, operasional, dan tenaga kerja. Kerja sama tersebut dituangkan dalam dokumen kontrak yang disepakati kedua belah pihak. Isi dokumen kontrak tersebut antara lain kontrak harga sarana produksi ternak (sapronak), harga jual ayam, bonus prestasi, dan SOP atau aturan main kerja samanya [1].

Sistem kemitraan dengan perusahaan kemitraan peternakan ayam menjadi salah satu strategi untuk meningkatkan efisiensi produksi. Peternak lebih memilih bekerjasama dengan perusahaan kemitraan karena harga pangan terhadap harga jual daging yang mengalami naik turun. Sistem kemitraan ini mengkombinasikan manajemen budidaya yang efektif dan sarana produksi ternak yang telah dijelaskan [2].

Adapun permasalahan yang umum muncul adalah pembukuan yang masih dilakukan secara manual, sehingga lebih rentan terjadinya kehilangan data. Permasalahan lainnya pada manajemen stok pakan ataupun vaksin yang tidak teratur, yang mana dapat berimbas pada kesalahan perhitungan pada estimasi pendapatan saat panen dilakukan. Permasalahan berikutnya pada saat pencatatan perkembangan ayam setiap hari yang kurang mendapatkan perhatian dari pihak kandang secara tertulis bahkan terlupakan [3]. Kemudian daripada itu, cara penanggulangan penyakit ayam yang dapat membuat bingung karyawan kandang juga menjadi permasalahan yang mendasar dalam beternak ayam broiler tersebut, dan pada saat panen dilakukan, proses penghitungan timbangan masih secara manual, sehingga rentan apabila terjadi kesalahan 
hitung, serta proses perhitungan dilakukan secara manual sehingga tidak efisien.

Untuk membantu dalam perancangan sistem ini penulis menggunakan metode prototyping, metode ini memiliki karakteristik yang mampu melakukan pendekatan terhadap user, sehingga sistem yang akan dibuat lebih dapat diterima dengan cepat oleh user.

Dari beberapa uraian permasalahan di atas, penulis merasa perlu adanya pembuatan sistem manajemen ayam broiler berbasis web agar dapat menunjang produktifitas dan efisiensi dalam beternak ayam broiler, sehingga dapat menghasilkan hasil panen yang maksimal.

\section{Tujuan :}

Adapun tujuan dari pembuatan proyek akhir ini adalah:

1) Mengimplementasikan metode prototyping terhadap perancangan sistem manajemen ayam broiler.

2) Membangun sebuah sistem yang dapat mengevaluasi perkembangan ayam broiler dan meningkatkan efektifitas dalam pemeliharaan ayam.

3) Memberikan informasi stock gudang agar bisa mengestimasi pakan yang akan di gunakan.

4) Memberikan informasi terkait penyakit, cara penangangan dan obat atau vaksin terhadap ayam broiler.

5) Memberikan informasi pendapatan keuntungan setelah panen.

\section{URAIAN PENELITIAN}

\section{Komoditas Ayam Broiler}

Ayam ras pedaging atau dikenal dengan istilah ayam broiler adalah ayam yang dihasilkan melalui perkawinan silang, seleksi dan rekayasa genetik yang dilakukan oleh pembibitnya. Ayam broiler merupakan jenis ayam ras unggulan hasil persilangan dari bangsa-bangsa ayam yang memiliki daya produktifitas tinggi, terutama dalam memproduksi daging ayam. Ayam broiler merupakan ayam yang memiliki kemampuan produksi daging sangat cepat sehingga saat ini banyak dikembangkan oleh masyarakat [4].

\section{Pola Kemitraan Peternak Ayam Broiler}

Pelaku usaha ternak ayam ras pedaging yang sebagian besar berbentuk peternakan rakyat, pada umumnya kelemahan utama di dalam usahanya terletak pada bidang permodalan ralatif kecil, kurang adanya kemampuan manajemen pemeliharaan, harga pakan relatif tinggi sedangkan kebutuhan ayam ras pedaging cukup besar berkisar antara 60 - 70\% dari biaya produksi. Masalah lain yang muncul yaitu dibidang pemasaran, karena belum memiliki pangsa pasar yang jelas sehingga harga yang diterima peternak dibawah harga pasar. Salah satu cara terbaik yang dapat dianjurkan dalam pengembangan agribisnis peternakan ayam broiler adalah menerapkan sistem koordinasi vertikal dengan pola kemitraan [5].
Secara teoritis kemitraan merupakan suatu cara pengorganisasian produksi yang bertujuan memanfaatkan keunggulan perusahaan besar sebagai pemilik modal yang lebih menekankan pada pemerataan. Hubungan kemitraan ini diasumsikan bahwa kedua belah pihak mempunyai kepentingan yang sama mendapatkan nilai tambah yang dirumuskan dalam suatu kontrak baik tertulis maupun tidak. Sistem ini tidak semata-mata berorientasi pada profit tapi juga peningkatan kesejahteraan, pertumbuhan ekonomi dan pengentasan kemiskinan. Melalui sistem ini, eksistensi hubungan inti-plasma diharapkan bersifat fungsional, sehingga terjadi hubungan saling ketergantungan dan saling menguntungkan kedua belah pihak.

Pola kemitraan dapat digunakan untuk mengatasi berbagai macam kekurangan yang dihadapi oleh peternak rakyat. Program pengembangan kemitraan merupakan salah satu kebijakan yang diterapkan oleh pemerintah untuk meningkatkan produksi ternak dan daging.

\section{- Kelebihan Beternak dengan Kemitraan}

Berikut beberapa kelebihan yang akan di dapat apabila menggunakan sistem beternak kemitraan dengan perusahaan :

1) Peternak (plasma) lebih diringankan dalam hal penyediaan modal awal budidaya.

2) Peternak tidak perlu memikirkan tentang pemasaran, karena sistem pemasaran telah dicover dengan baik oleh perusahaan inti, dengan harga sesuai kontrak.

3) Selama usaha budidaya berjalan lancar (ayam sehat dan panen tepat waktu) peternak tidak akan pernah merugi walaupun harga ayam di pasaran turun drastis, sebab harga telah ditetapkan dikontrak awal.

\section{- Kekurangan Beternak dengan Kemitraan}

Dari beberapa kelebihan yang dipaparkan sebelumnya, sistem beternak ayam broiler tidak luput dari kekurangan, seperti :

1) Plasma tidak memiliki kebebasan penuh terhadap usaha budidaya, karena semua sistem manajemen kandang, pemberian pakan, dan teknis budidaya telah diatur oleh perusahaan inti dengan mengirimkan pendamping.

2) Plasma tidak bisa mendapat untung besar walaupun harga ayam potong dipasaran melambung tinggi, karena harga telah ditetapkan.

\section{Pengujian Blackbox Testing}

Black-Box Testing yaitu menguji perangkat lunak dari segi spesifikasi fungsional tanpa menguji lebih detail desain dan kode program. Pengujian dimaksud untuk mengetahui apakah fungsi-fungsi, masukan, dan keluaran dari perangkat lunak sesuai dengan spesifikasi yang dibutuhkan. 


\section{Metode Prototyping}

Prototyping dapat disebut juga desain aplikasi cepat (Rapid Aplication Design / RAD) karena menyederhanakan dan mempercepat dalam mendesain system [6]. Adapun alasan peneliti dalam mengambil metode prototyping sebagai metode perancangan sistem dikarenakan telah melakukan perbandingan terhadap beberapa metode seperti metode waterfall dan spiral. Metode prototyping melibatkan user dalam analisis dan desain sistem sehingga lebih menghemat waktu dalam pengembangan sistem, dan penerapannya lebih mudah karena user mengetahui apa yang diharapkannya.

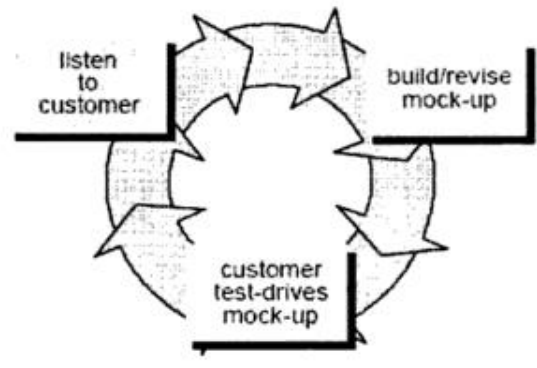

Gambar 1 - Alur metode prototyping

\section{HASIL DAN PEMBAHASAN}

1. Identifikasi Use Case

Use case diagram menjelaskan mengenai aktor - aktor yang terlibat dengan perangkat lunak atau sistem yang dibangun beserta proses - proses yang ada didalamnya. Use case diagram dari sistem manajemen budidaya ayam broiler sebagai berikut :

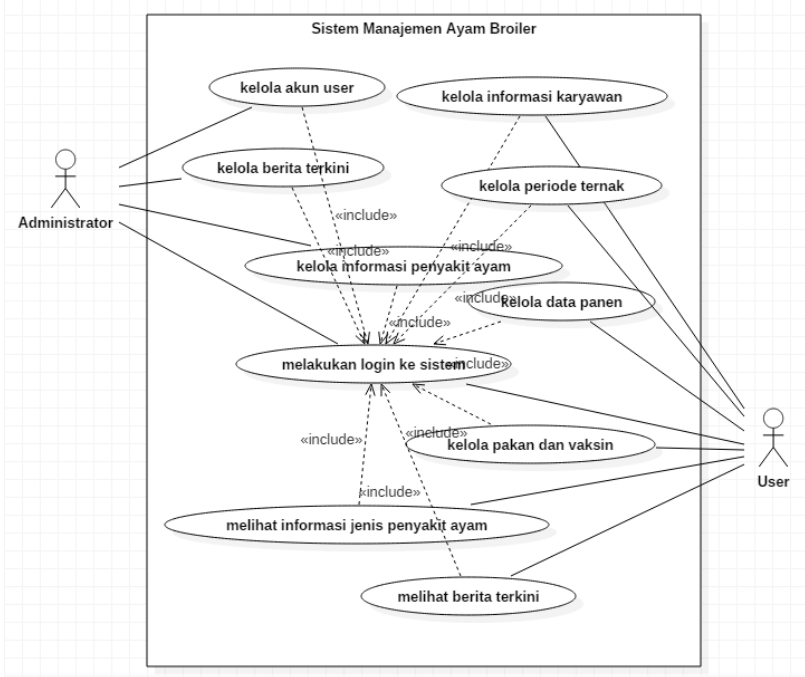

Gambar 2 - Use Case Sistem

\section{Identifikasi E-ERD}

Pada kesempatan kali ini akan dibutuhkan beberapa entitas untuk membangun sistem manajemen yang diinginkan, adapun susunan dan relasi dari setiap tabel yang dibutuhkan tersebut yang menggunakan standarisasi ERD yang telah dijelaskan sebelumnya, terlihat pada gambar berikut ini :

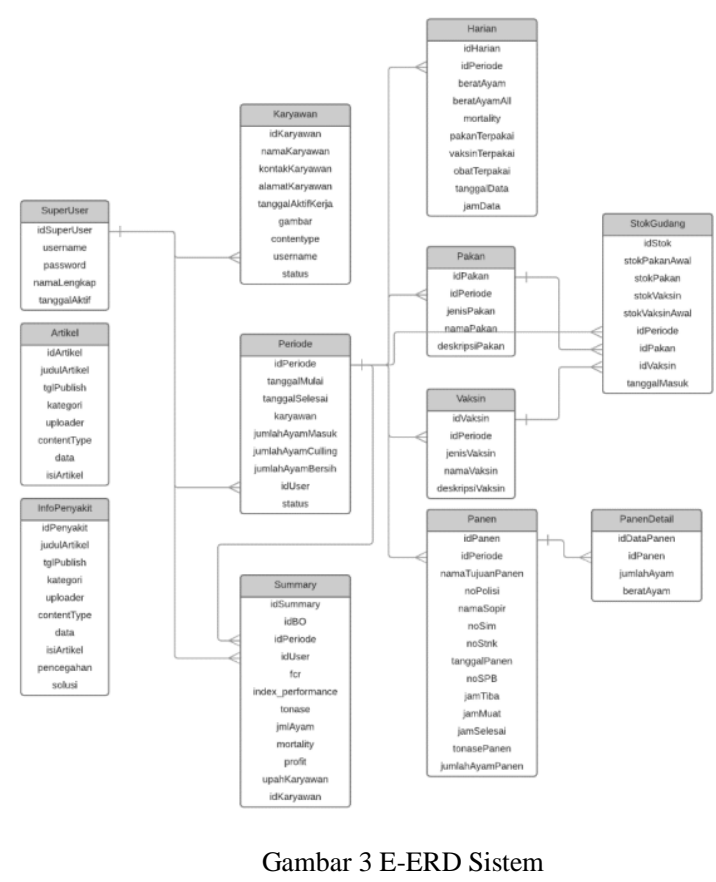

3. Prototype Sistem

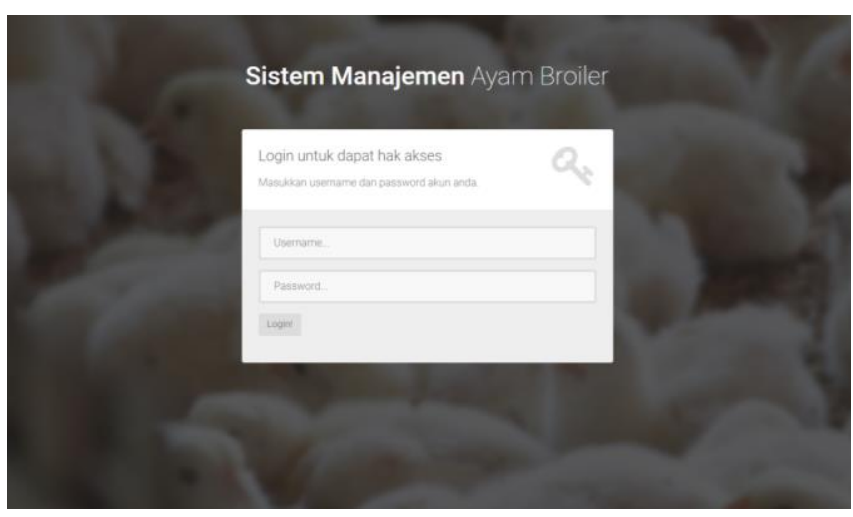

Gambar 4 Halaman login sistem 


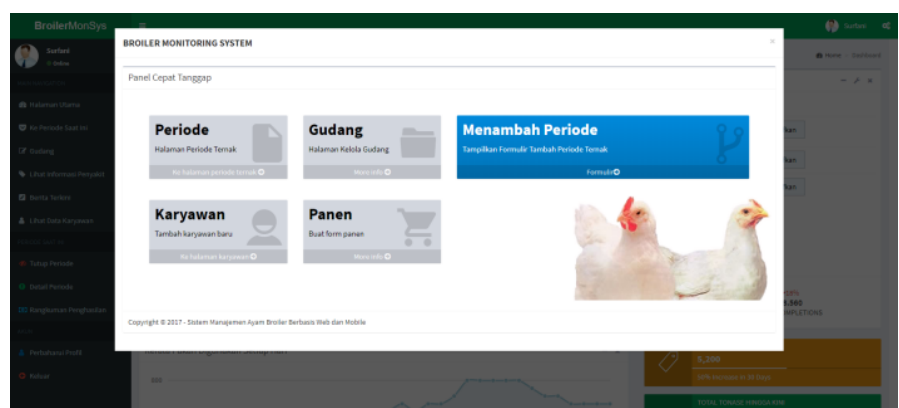

Gambar 5 Halaman utama sistem
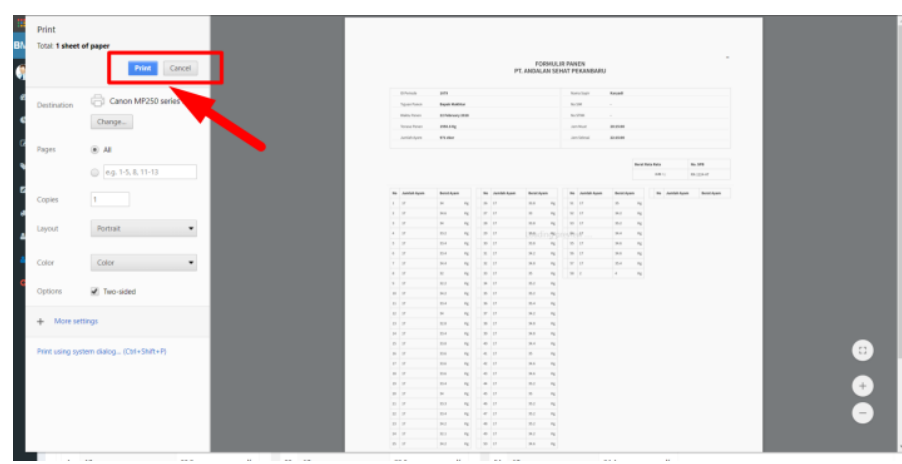

Gambar 6 Halaman cetak formulir panen

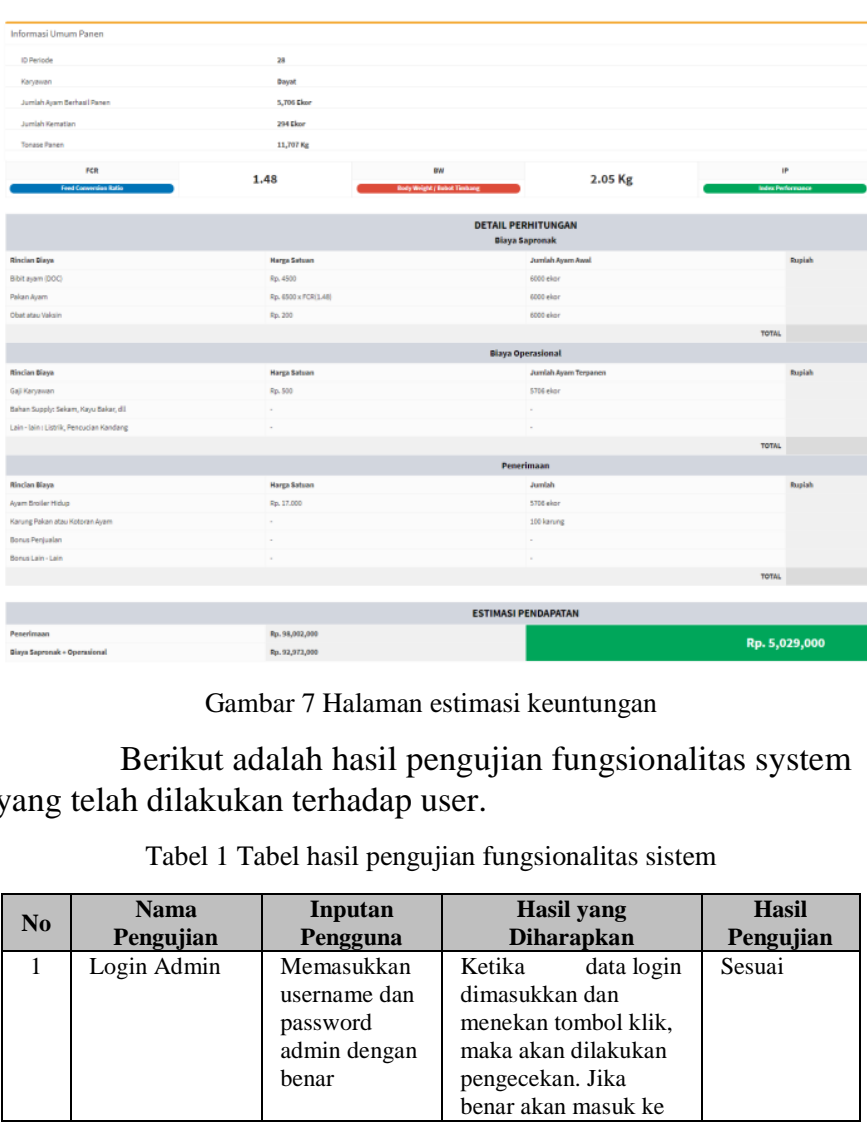

\begin{tabular}{|c|c|c|c|c|}
\hline No & $\begin{array}{c}\text { Nama } \\
\text { Pengujian }\end{array}$ & $\begin{array}{l}\text { Inputan } \\
\text { Pengguna }\end{array}$ & $\begin{array}{c}\text { Hasil yang } \\
\text { Diharapkan } \\
\end{array}$ & $\begin{array}{c}\text { Hasil } \\
\text { Pengujian }\end{array}$ \\
\hline & & & halaman admin. & \\
\hline 2 & Tambah User & $\begin{array}{l}\text { Memasukkan } \\
\text { data } \text { user yang } \\
\text { tampil pada } \\
\text { formulir } \\
\text { penambahan } \\
\text { user }\end{array}$ & $\begin{array}{l}\text { Ketika tombol simpan } \\
\text { diklik, maka akan } \\
\text { menyimpan ke } \\
\text { database dan } \\
\text { menampilkan list user. }\end{array}$ & Sesuai \\
\hline 3 & Hapus User & $\begin{array}{l}\text { Menekan } \\
\text { tombol hapus } \\
\text { pada user } \\
\text { yang akan } \\
\text { dihapus. }\end{array}$ & $\begin{array}{l}\text { Ketika tombol hapus } \\
\text { di klik, sistem akan } \\
\text { menghapus data user } \\
\text { tersebut dan kembali } \\
\text { menampilkan halaman } \\
\text { admin. }\end{array}$ & Sesuai \\
\hline 4 & Update User & $\begin{array}{l}\text { Menekan } \\
\text { tombol update } \\
\text { pada user } \\
\text { yang akan } \\
\text { diupdate }\end{array}$ & $\begin{array}{l}\text { Ketika tombol update } \\
\text { di klik, muncul } \\
\text { formulir update. Dan } \\
\text { ketika tombol } \\
\text { Perbaharui di klik, } \\
\text { sistem akan } \\
\text { menyimpan data baru } \\
\text { tersebut dan kembali } \\
\text { menampilkan halaman } \\
\text { admin. }\end{array}$ & Sesuai \\
\hline 5 & Tambah Berita & $\begin{array}{l}\text { Memasukkan } \\
\text { data berita } \\
\text { yang tampil } \\
\text { pada formulir } \\
\text { penambahan } \\
\text { berita. }\end{array}$ & $\begin{array}{l}\text { Ketika tombol simpan } \\
\text { diklik, maka akan } \\
\text { menyimpan ke } \\
\text { database dan } \\
\text { menampilkan list } \\
\text { berita pada halaman } \\
\text { admin. } \\
\end{array}$ & Sesuai \\
\hline 6 & Hapus Berita & $\begin{array}{l}\text { Menekan } \\
\text { tombol hapus } \\
\text { pada daftar } \\
\text { berita yang } \\
\text { akan dihapus. }\end{array}$ & $\begin{array}{l}\text { Ketika tombol hapus } \\
\text { di klik, sistem akan } \\
\text { menghapus data berita } \\
\text { tersebut dan kembali } \\
\text { menampilkan halaman } \\
\text { admin. }\end{array}$ & Sesuai \\
\hline 375.37 & 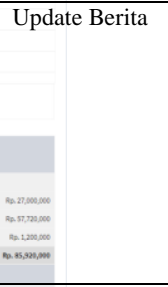 & $\begin{array}{l}\text { Menekan } \\
\text { tombol update } \\
\text { pada daftar } \\
\text { berita yang } \\
\text { akan diupdate }\end{array}$ & $\begin{array}{l}\text { Ketika tombol update } \\
\text { di klik, muncul } \\
\text { formulir update. Dan } \\
\text { ketika tombol } \\
\text { Perbaharui di klik, } \\
\text { sistem akan } \\
\text { menyimpan data baru } \\
\text { tersebut dan kembali } \\
\text { menampilkan halaman } \\
\text { admin. }\end{array}$ & Sesuai \\
\hline 8 & 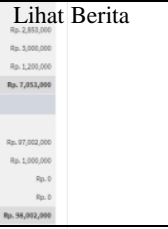 & $\begin{array}{l}\text { Menekan } \\
\text { tombol lihat } \\
\text { atau logo } \\
\text { mata pada } \\
\text { daftar berita } \\
\text { yang akan } \\
\text { dilihat } \\
\text { rinciannya. } \\
\end{array}$ & $\begin{array}{l}\text { Ketika tombol lihat } \\
\text { berita di klik, akan } \\
\text { tampil halaman } \\
\text { dengan memuat } \\
\text { informasi berita yang } \\
\text { lebih lengkap. }\end{array}$ & Sesuai \\
\hline 9 & $\begin{array}{l}\text { Logout } \\
\text { Admin }\end{array}$ & $\begin{array}{l}\text { Menekan } \\
\text { tombol logout }\end{array}$ & $\begin{array}{l}\text { Sistem kembali ke } \\
\text { halaman login dan } \\
\text { session admin sudah } \\
\text { tidak ada }\end{array}$ & Sesuai \\
\hline 10 & Login User & $\begin{array}{l}\text { Memasukkan } \\
\text { username dan } \\
\text { password user } \\
\text { dengan benar }\end{array}$ & $\begin{array}{l}\text { Ketika data login } \\
\text { user dimasukkan dan } \\
\text { menekan tombol klik, } \\
\text { maka akan dilakukan } \\
\text { pengecekan. Jika } \\
\text { benar akan masuk ke } \\
\text { halaman user. }\end{array}$ & Sesuai \\
\hline 11 & Logout User & $\begin{array}{l}\text { Menekan } \\
\text { tombol logout }\end{array}$ & $\begin{array}{l}\text { Sistem kembali ke } \\
\text { halaman login dan } \\
\text { session user tersebut } \\
\text { sudah tidak ada. }\end{array}$ & Sesuai \\
\hline 12 & $\begin{array}{l}\text { Tambah } \\
\text { Periode }\end{array}$ & $\begin{array}{l}\text { Menekan } \\
\text { tombol } \\
\text { tambah }\end{array}$ & $\begin{array}{l}\text { Sistem menyimpan } \\
\text { data periode baru ke } \\
\text { database dan secara }\end{array}$ & Sesuai \\
\hline
\end{tabular}




\begin{tabular}{|c|c|c|c|c|}
\hline No & $\begin{array}{c}\text { Nama } \\
\text { Pengujian }\end{array}$ & $\begin{array}{c}\text { Inputan } \\
\text { Pengguna }\end{array}$ & $\begin{array}{c}\text { Hasil yang } \\
\text { Diharapkan }\end{array}$ & $\begin{array}{c}\text { Hasil } \\
\text { Pengujian }\end{array}$ \\
\hline & & $\begin{array}{l}\text { periode pada } \\
\text { panel cepat } \\
\text { tanggap yang } \\
\text { muncul saat } \\
\text { pertama } \\
\text { halaman user } \\
\text { di load. }\end{array}$ & $\begin{array}{l}\text { otomatis periode } \\
\text { tersebut menjadi } \\
\text { periode yang aktif. }\end{array}$ & \\
\hline 13 & $\begin{array}{l}\text { Update Detail } \\
\text { Periode }\end{array}$ & $\begin{array}{l}\text { Menekan } \\
\text { tombol } \\
\text { Perbaharui } \\
\text { Periode pada } \\
\text { halaman } \\
\text { periode yang } \\
\text { aktif. }\end{array}$ & $\begin{array}{l}\text { Sistem menyimpan } \\
\text { data pembaharuan dari } \\
\text { periode tersebut dan } \\
\text { kembali menampilkan } \\
\text { halaman periode yang } \\
\text { aktif. }\end{array}$ & Sesuai \\
\hline 14 & $\begin{array}{l}\text { Estimasi } \\
\text { keuntungan }\end{array}$ & $\begin{array}{l}\text { Menekan } \\
\text { tombol } \\
\text { Estimasi } \\
\text { Keuntungan }\end{array}$ & $\begin{array}{l}\text { Halaman estimasi } \\
\text { keuntungan dengan } \\
\text { beberapa perhitungan } \\
\text { akan muncul. }\end{array}$ & Sesuai \\
\hline 15 & $\begin{array}{l}\text { Tambah Pakan } \\
\text { dan Vaksin }\end{array}$ & $\begin{array}{l}\text { Menekan } \\
\text { tombol } \\
\text { Gudang untuk } \\
\text { menampilkan } \\
\text { formulir } \\
\text { penambahan }\end{array}$ & $\begin{array}{l}\text { Sistem menampilkan } \\
\text { formulir penambahan } \\
\text { dan kemudian } \\
\text { menyimpan data pakan } \\
\text { dan vaksin setelah di } \\
\text { klik tombol Tambah. }\end{array}$ & Sesuai \\
\hline 16 & $\begin{array}{l}\text { Tambah Data } \\
\text { Harian }\end{array}$ & $\begin{array}{l}\text { Menekan } \\
\text { tombol Harian } \\
\text { untuk } \\
\text { menampilkan } \\
\text { formulir } \\
\text { penambahan } \\
\text { data harian. }\end{array}$ & $\begin{array}{l}\text { Sistem menampilkan } \\
\text { formulir penambahan } \\
\text { dan kemudian } \\
\text { menyimpan data harian } \\
\text { setelah di klik tombol } \\
\text { Tambah. }\end{array}$ & Sesuai \\
\hline 17 & $\begin{array}{l}\text { Hapus Pakan } \\
\text { atau Vaksin }\end{array}$ & $\begin{array}{l}\text { Menekan } \\
\text { tombol hapus } \\
\text { pada daftar } \\
\text { pakan atau } \\
\text { vaksin. }\end{array}$ & $\begin{array}{l}\text { Sistem menghapus data } \\
\text { pakan atau vaksin yang } \\
\text { dipilih dan kembali } \\
\text { menampilkan halaman } \\
\text { gudang. }\end{array}$ & Sesuai \\
\hline 18 & $\begin{array}{l}\text { Ubah Data } \\
\text { Harian }\end{array}$ & $\begin{array}{l}\text { Menekan } \\
\text { tombol } \\
\text { Update pada } \\
\text { daftar } \\
\text { perkembanga } \\
\mathrm{n} \text { harian. }\end{array}$ & $\begin{array}{l}\text { Sistem menampilkan } \\
\text { halaman dengan } \\
\text { formulir pembaharuan } \\
\text { data harian. Apabila } \\
\text { tombol Perbaharui di } \\
\text { klik, maka sistem akan } \\
\text { menyimpan data yang } \\
\text { baru tersebut dan } \\
\text { kembali menampilkan } \\
\text { halaman Periode. }\end{array}$ & Sesuai \\
\hline 19 & $\begin{array}{l}\text { Hapus Data } \\
\text { Harian }\end{array}$ & $\begin{array}{l}\text { Menekan } \\
\text { tombol hapus } \\
\text { pada daftar } \\
\text { harian. }\end{array}$ & $\begin{array}{l}\text { Sistem menghapus data } \\
\text { harian yang dipilih dan } \\
\text { kembali menampilkan } \\
\text { halaman Periode. }\end{array}$ & Sesuai \\
\hline 20 & $\begin{array}{l}\text { Lihat Info } \\
\text { Penyakit }\end{array}$ & $\begin{array}{l}\text { Memilih } \\
\text { menu info } \\
\text { penyakit }\end{array}$ & $\begin{array}{l}\text { Sistem menampilkan } \\
\text { halaman dengan } \\
\text { berbagai informasi } \\
\text { penyakit }\end{array}$ & Sesuai \\
\hline 21 & $\begin{array}{l}\text { Lihat Profil } \\
\text { User }\end{array}$ & $\begin{array}{l}\text { Menekan } \\
\text { tombol Profil }\end{array}$ & $\begin{array}{l}\text { Menampilkan halaman } \\
\text { profil user }\end{array}$ & Sesuai \\
\hline 22 & $\begin{array}{l}\text { Update Profil } \\
\text { User }\end{array}$ & $\begin{array}{l}\text { Memilih } \\
\text { tombol } \\
\text { Update Profil }\end{array}$ & $\begin{array}{l}\text { Sistem menampilkan } \\
\text { formulir perbaharuan } \\
\text { akun user. Apabila di } \\
\text { klik tombol Perbaharui } \\
\text { maka sistem akan } \\
\text { menyimpannya dan } \\
\text { kembali menampilkan } \\
\text { halaman Profil. }\end{array}$ & Sesuai \\
\hline 22 & Panen Periode & $\begin{array}{l}\text { Memilih } \\
\text { tombol Panen }\end{array}$ & $\begin{array}{l}\text { Sistem menampilkan } \\
\text { formulir panen dan } \\
\text { setelah proses panen } \\
\text { selesai yang ditandai } \\
\text { dengan menekan } \\
\text { tombol Simpan, sistem } \\
\text { kembali melakukan } \\
\text { kalkulasi terhadap } \\
\text { pengurangan jumlah } \\
\text { ternak yang ada } \\
\text { dikandang lalu } \\
\text { memperbaharuinya. }\end{array}$ & Sesuai \\
\hline
\end{tabular}

\begin{tabular}{|c|c|c|c|c|}
\hline No & $\begin{array}{c}\text { Nama } \\
\text { Pengujian }\end{array}$ & $\begin{array}{l}\text { Inputan } \\
\text { Pengguna }\end{array}$ & $\begin{array}{c}\text { Hasil yang } \\
\text { Diharapkan }\end{array}$ & $\begin{array}{c}\text { Hasil } \\
\text { Pengujian }\end{array}$ \\
\hline 24 & $\begin{array}{l}\text { Rekapitulasi } \\
\text { Panen }\end{array}$ & $\begin{array}{l}\text { Menekan } \\
\text { tombol Lihat } \\
\text { Detail pada } \\
\text { Panel Catatan } \\
\text { Panen }\end{array}$ & $\begin{array}{l}\text { Menampilkan detail } \\
\text { panen yang telah } \\
\text { dilakukan yang } \\
\text { meliputi informasi } \\
\text { umum, berat rata-rata, } \\
\text { dan tabel yang memuat } \\
\text { jumlah ayam yang } \\
\text { dipanen. }\end{array}$ & Sesuai \\
\hline 25 & $\begin{array}{l}\text { Cetak Form } \\
\text { Hasil Panen }\end{array}$ & $\begin{array}{l}\text { Menekan } \\
\text { tombol Print } \\
\text { pada Halaman } \\
\text { Detail Panen }\end{array}$ & $\begin{array}{l}\text { Menampilkan formulir } \\
\text { siap print yang sesuai } \\
\text { dengan format dari } \\
\text { perusahaan inti terkait } \\
\text { formulir panen yang } \\
\text { dikeluarkannya }\end{array}$ & Sesuai \\
\hline 26 & $\begin{array}{l}\text { Estimasi } \\
\text { Penghasilan }\end{array}$ & $\begin{array}{l}\text { User menekan } \\
\text { tombol } \\
\text { Estimasi } \\
\text { Penghasilan } \\
\text { pada menu } \\
\text { kiri } \\
\end{array}$ & $\begin{array}{l}\text { Sistem menampilkan } \\
\text { rekapitulasi dana dan } \\
\text { penghasilan }\end{array}$ & Sesuaiu \\
\hline
\end{tabular}

\section{Analisis Blackbox Testing}

Berdasarkan hasil pengujian blackbox testing yang telah diujikan kepada klien atau peternak tempat studi kasus proyek akhir ini yaitu Bapak Surfani, SE., pengujian fungsional telah dilakukan menggunakan test case, maka diperoleh hasil bahwa sistem manajemen ayam broiler ini telah berjalan sesuai dengan kesepakatan bersama dan berjalan dengan baik.

\section{Analisis Kuesioner}

Dari pengujian kuesioner yang telah dilakukan, dapat disimpulkan sebagai berikut:

Berdasarkan kuesioner yang diisi oleh user, didapatkan kesimpulan $82 \%$ responden berpendapat sangat setuju untuk pernyataan pertama, $82 \%$ responden berpendapat sangat setuju untuk pernyataan kedua, $82 \%$ responden berpendapat setuju untuk pernyataan ketiga, $92 \%$ responden berpendapat sangat setuju untuk pernyataan keempat, $88 \%$ responden berpendapat sangat setuju untuk pernyataan kelima, $88 \%$ responden berpendapat sangat setuju untuk pernyataan keenam, $82 \%$ responden berpendapat sangat setuju untuk pernyataan ketujuh, $70 \%$ responden berpendapat setuju untuk pernyataan kedelepan, $86 \%$ responden berpendapat sangat setuju untuk pernyataan kesembilan, dan 78 responden berpendapat setuju untuk pernyataan kesepuluh. Sehingga rata-rata keseluruhan dari pernyataan kuesioner yang didapat adalah 82,6\% (Sangat Setuju).

Dari persentase tersebut dapat dianalisa bahwa sistem manajemen ayam broiler yang dibangun memiliki pengaruh besar bagi hasil akhir dari periode ternak yang dijalani. Salah satunya dari pernyataan kuesioner ke-10, user setuju bahwa sistem ini meningkatkan efisiensi dalam beternak dan lebih efektif dalam pengelolaan kandang ternak.

6. Perbandingan Hasil Periode Ternak

Adapun perbandingan pendapatan yang didapatkan setelah memakai sistem dengan pendapatan sebelum memakai sistem dapat dilihat pada tabel berikut ini : 
Tabel 2 tabel perbandingan penghasilan sebelum dan setelah memakai sistem

\begin{tabular}{|l|c|c|c|c|}
\cline { 2 - 5 } \multicolumn{1}{c|}{} & Sebelum & \multicolumn{3}{c|}{ Sesudah } \\
\hline Item & September & Januari & Maret & Mei \\
\hline $\begin{array}{l}\text { Tonase } \\
\text { panen } \\
\text { (kg) }\end{array}$ & 10.670 & 11.707 & 11.174 & 11.802 \\
\hline $\begin{array}{l}\text { FCR } \\
\text { Fortality }\end{array}$ & $4,85 \%$ & $5,15 \%$ & $3,52 \%$ & $4,77 \%$ \\
\hline \%) & 307 & 375,37 & 301,11 & 357,46 \\
\hline $\begin{array}{l}\text { Index } \\
\text { Performance }\end{array}$ & 3.500 .000 & $\mathbf{5 . 5 9 9 . 6 0 0}$ & $\mathbf{7 . 7 9 1 . 3 0 0}$ & $\mathbf{2 . 2 3 1 . 4 7 0}$ \\
\hline $\begin{array}{l}\text { Penghasilan } \\
\text { Bersih } \\
\text { (Rp.) }\end{array}$ & 1,48 & 1,70 & 1,69 \\
\hline
\end{tabular}

Catatan :Data pada periode September dan November didapat langsung dari dokumentasi klien sebelum memakai sistem.

7. Analisis Kebermanfaatan Sistem dari Penghasilan Perbandingan pendapatan ini maksudnya adalah perbandingan antara pendapatan faktual, dengan pendapatan yang dikalkulasikan oleh sistem serta pendapatan yang dikalkulasikan manual oleh klien sebelum memakai sistem.

Tabel 3 tabel perbandingan perhitungan system dengan perhitungan manual

\begin{tabular}{|c|c|c|c|}
\hline & \multicolumn{3}{|c|}{ Pendapatan (Rp.) } \\
\hline Jen & Faktual & $\begin{array}{l}\text { Perhitungan } \\
\text { Manual }\end{array}$ & $\begin{array}{c}\text { Perhitungan oleh } \\
\text { Sistem }\end{array}$ \\
\hline \multirow{2}{*}{$\begin{array}{c}\text { Juli } \\
2017\end{array}$} & $4.350 .000,-$ & $3.500 .000,-$ & - \\
\hline & Rasio perbandingan & $19.54 \%$ & - \\
\hline \multirow{2}{*}{$\begin{array}{c}\text { September } \\
2017\end{array}$} & $3.500 .000,-$ & $5.600 .000,-$ & - \\
\hline & Rasio perbandingan & $37.5 \%$ & - \\
\hline \multirow{2}{*}{ Januari 2018} & $5.100 .000,-$ & $5.700 .000,-$ & $5.599 .600,-$ \\
\hline & Rasio perbandingan & $11,76 \%$ & $9,7 \%$ \\
\hline \multirow{2}{*}{ Maret 2018} & 7.610.000,- & 7.300.000,- & 7.791.300,- \\
\hline & Rasio perbandingan & $4,07 \%$ & $2,38 \%$ \\
\hline \multirow{2}{*}{$\begin{array}{l}\text { Mei } \\
2018\end{array}$} & $-2.500 .000,-$ & $3.200 .000,-$ & $-2.231 .470,-$ \\
\hline & Rasio perbandingan & $228 \%$ & $10,7 \%$ \\
\hline \multicolumn{2}{|c|}{$\begin{array}{l}\text { Rerata rasio terhadap pendapatan } \\
\text { faktual }\end{array}$} & $60.174 \%$ & $7.59 \%$ \\
\hline
\end{tabular}

Rasio tersebut adalah perbandingan terhadap penghasilan faktual, sehingga dapat disimpulkan bahwa sistem dapat memberikan informasi estimasi pendapatan lebih akurat daripada perhitungan manual karena rasio nya relatif lebih kecil.

\section{KESIMPULAN}

Kesimpulan yang diperoleh dari penelitian ini sebagai berikut:

1. Metode prototyping telah diimplementasikan dengan baik dalam membantu perancangan sistem ini, yang mana sistem yang dibangun sudah mengikuti permintaan klien, sehingga waktu penyelesaian sistem jadi lebih cepat.

2. Sistem berhasil memberikan dan menyediakan fitur yang dapat merekam data perkembangan ayam setiap harinya, dan user dapat melihat perkembangan tersebut dalam grafik yang tersedia di sistem.

3. Pakan yang diberikan kepada ternak menjadi lebih efisien akibat dari rekomendasi yang diberikan oleh sistem.

4. Sistem memberikan informasi - informasi terbaru seputar ternak ayam broiler atau unggas pada umumnya, dan sistem juga memberikan informasi terkait cara pencegahan maupun penanganan terhadap ayam dengan gejala penyakit tertentu.

5. Sistem memberikan informasi estimasi keuntungan sementara setelah segala proses panen telah dilakukan.

6. Sistem dapat menyimpan dan menentukan karyawan yang bekerja pada periode tertentu.

7. Berdasarkan pengujian UAT, fungsionalitas sistem telah disetujui $100 \%$ oleh klien.

8. Berdasarkan hasil dari analisis kuesioner, user setuju bahwa sistem manajemen ayam broiler ini mampu meningkatkan efisiensi beternak dan lebih efektif dalam pengelolaan kendang ternak selama periode berjalan.

9. Berdasarkan analisis pendapatan, klien merasa senang dengan adanya fitur estimasi keuntungan tersebut, hal ini membuat klien atau user dapat memprediksi besaran untung ataupun rugi yang didapatkan dalam periode yang telah berjalan.

\section{UCAPAN TERIMA KASIH / ACKNOWLEDGMENT}

Segala puji syukur kehadirat Allah SWT yang telah melimpahkan rahmat dan barokah-Nya sehingga penulis dapat menyelesaikan proyek akhir yang berjudul "RANCANG BANGUN SISTEM MANAJEMEN BUDIDAYA AYAM BROILER BERBASIS WEB MENGGUNAKAN METODE PROTOTYPING". Proyek akhir ini disusun sebagai salah satu syarat untuk menyelesaikan jenjang pendidikan Diploma IV pada Program Studi Teknik Informatika Politeknik Caltex Riau.

Pada kesempatan ini, penulis ingin mengucapkan terima kasih kepada pihak yang telah banyak memberikan 
bantuan dan dukungan yang tiada terhingga baik secara langsung maupun tidak langsung. Ucapan terima kasih tersebut penulis tujukan kepada:

1. Kedua orang tua penulis atas dukungan dan kasih sayang tak terhingga, sehingga penulis bisa menyelesaikan proyek akhir tepat waktu.

2. Keluarga besar yang selalu memberikan dukungan penuh kepada penulis.

3. Dr. Hendriko, S.T., M.Eng. selaku Direktur Politeknik Caltex Riau.

4. Bapak Ibnu Surya, S.T., M.T. dan Bapak Maksum Rois Adin Saf, S.Kom., M.Eng. selaku dosen pembimbing, yang telah memberikan ilmu dan bimbingan dengan penuh kesabaran kepada penulis dalam menyelesaikan proyek akhir.

5. Ibu Rika Perdana Sari, S.T., M.Eng. selaku dosen wali.

6. Seluruh dosen khususnya Program Studi Teknik Informatika dan seluruh dosen di Politeknik Caltex Riau pada umumnya yang telah memberikan bekal ilmu kepada penulis dalam menyelesaikan proyek akhir.

7. Teman-teman TI A Generasi 14 dan Generasi 14 Information Technology Student Association (ITSA) seperjuangan yang telah memberikan dukungan dan semangat dalam menyelesaikan proyek akhir ini.

8. Keluarga channel 14 yang selalu memberikan dukungan.

9. Semua pihak yang turut membantu penulis dalam menyelesaikan proyek akhir yang tidak dapat penulis sebutkan satu per satu.

Penulis sangat menyadari sepenuhnya bahwa laporan proyek akhir ini masih jauh dari sempurna, oleh karena itu segala jenis kritik, saran dan masukan yang membangun sangat penulis harapkan agar dapat memberikan wawasan bagi pembaca dan yang paling utama penulis sendiri.

\section{REFERENSI}

[1] R. P. Hartanto, "Forum Pertanian Terbesar di Indonesia," 15 Maret 2016. [Online]. Available: https://www.pertanianku.com/mengenal-sistem-kontrakdalam-usaha-ayam-broiler/.

[2] F. M. Riza, "Rancang Bangun Sistem Penunjang Keputusan Waktu Panen Ayam Broiler Menggunakan Metode Topsis," Rancang Bangun Sistem Penunjang Keputusan, p. 7, 2015.

[3] F. Rahman, “APLIKASI PETERNAKAN AYAM BROILER BERBASIS ANDROID," Aplikasi Peternakan Ayam Broiler, p. 3, 2016.

[4] H. Santoso and T. Sudaryani, Panduan Praktis Pembesaran Ayam Pedaging, Tangerang: Penebar Swadaya, 2015.

[5] H. F. Ilmu Usaha Tani, Jakarta: Penebar Swadaya, 1989.

[6] R. A.S and M. Shalahuddin, Rekayasa Perangkat Lunak
Terstruktur dan Berorientasi Objek, Bandung: Informatika Bandung, 2013.

[7] J. A. O'Brien, Introduction to Information Systems, GrewHill, Northern: Raymorid Jr. and George Schell, 2005. 